\title{
The Effect of Managers' Trust in Subordinate on Entrepreneurial Intention: A Research on SMEs
}

\section{Yöneticilerin Asta Güven Düzeyinin Girişimcilik Niyetine Etkisi: KOBİ’lere Yönelik Bir Araştırma}

\section{H. Tezcan UYSAL ${ }^{*}$}

\begin{abstract}
This research aims to determine the entrepreneurial intention and trust levels of the individuals' who have conducted entrepreneurship activities before and worked as managers in the SME founded by themselves. The second aim is to determine whether there is a significant relationship between these levels and if there is, to investigate the effect of the manager's trust to subordinate on the entrepreneurial intention as well as the roles of gender and entrepreneurial training on this effect. In this context, data has been obtained from 304 SME managers via survey method. The obtained data has been processed with SPSS 20.0 program and as a result of the analyzes performed, a positive relationship has been found between the entrepreneurial intentions of SME managers and trust to subordinates and the dimensions thereof; it has been determined that the increase in the trust to employees for troubleshooting and the increase in the trust to employees for the achievement of organizational tasks have affected the managers' entrepreneurial intention positively. However, it has also been found that gender and entrepreneurial training cause a difference on the relationship between the trust to subordinate and entrepreneurial intention. It has been determined that it is sufficient for male managers to see that subordinates can solve problems in order to increase entrepreneurial intention; however, for female managers, subordinates' solving problems do not have a meaningful effect and subordinates' successfully running the organizational tasks is sufficient for the entrepreneurial intention. However, for SME managers with entrepreneurial training, it has been found that the subordinates' successfully running organizational tasks is an important factor for the continuance of entrepreneurship and for the SME managers who has not received entrepreneurial training, it has been found that the subordinates' capability for troubleshooting and trust to the subordinates' decisions are more significant.
\end{abstract}

Keywords: Entrepreneurial Intention, Trust, Subordinate, Organizational Atmosphere

Öz

Bu araştırmanın amacı; daha önce girişimcilik faaliyetinde bulunarak kurmuş olduğu KOBİ'de yöneticilik yapan bireylerin mevcut girişimcilik niyeti ile asta güven düzeyini saptamak, bu düzeyler arasında anlamlı bir ilişki olup olmadığını belirlemek, eğer anlamlı bir ilişki var ise yöneticilerin asta güven düzeyinin girişimcilik niyeti üzerindeki etkisini incelemek ve bu etki üzerinde cinsiyet ile girişimcilik eğitiminin rolünü tespit etmektir. Bu kapsamda 304 KOBİ yöneticisinden anket yöntemiyle veri elde edilmiştir. Elde edilen veriler SPSS 20.0 programıyla işlenmiş, gerçekleştirilen analizler sonucunda; KOBİ yöneticilerinin girişimcilik niyeti ile asta güven ve asta güvenin boyutları arasında pozitif yönde anlamlı bir ilişki saptanmış, çalışanların sorunları gidermesine yönelik güvendeki artışın ve çalışanların örgütsel işleri başarmasına yönelik güvendeki artışın yöneticilerin girişimcilik niyetini olumlu yönde etkilediği belirlenmiştir. Bununla birlikte asta güven ile girişimcilik niyeti arasındaki ilişki üzerinde cinsiyetin ve girişimcilik eğitiminin de farklılığa neden olduğu saptanmıştır. Erkek yöneticilerin girişimcilik niyetinin arttırabilmesi için astların sorunları çözebildiğini görmesinin yeterli olduğu, kadın yöneticilerde ise aksine astların sorunları çözmesinin anlamlı bir etkisinin olmadığı, girişimcilik niyeti için astların örgütsel işleri başarıyla yürütmesinin tek başına yeterli olduğu belirlenmiştir. Bununla birlikte girişimcilik eğitimi almış KOBİ yöneticilerinde girişimciliğin devamlılığı için astların örgütsel işleri başarıyla yürütmesinin tek başına önemli bir unsur olduğu, girişimcilik eğitimi almamış KOBİ yöneticilerinde ise astların sorunları giderebilmesi ve astların aldığı kararlara olan güvenin daha önemli olduğu tespit edilmiştir.

Anahtar Kelimeler: Girişimcilik Niyeti, Güven, Ast, Örgüt Atmosferi

\section{Introduction}

From past to present, trust is one of the unchanging factors in the development process of organizations. Trust between employees and employers is one of the definite factors in achieving productivity, productivity and goals (Yücel and Samanc1, 2009). In the literature, a

\footnotetext{
*Lect. Dr., Bülent Ecevit University, Zonguldak Vocational School, Department of Management and Organization, Zonguldak, h.tezcanuysal@hotmail.com
}

Uysal, H. T. (2019). The Effect of Managers' Trust in Subordinate on Entrepreneurial Intention: A Research on SMEs, Gaziantep University Journal of Social Sciences, 18 (2), 565-580, Submission Date: 24-06-2018, 
consensus has been reached that trust is needed for organizational success, but it is not created in short term and long and self-sacrificing efforts are required (Sipahioğlu and Öner, 2013). Therefore, employees need to work together by receiving help from each other in order to achieve personal and organizational goals. This is only possible with the trust created within the organization (Bat1 and Tutar, 2016). Employees perceive the trust within the organizational atmosphere when the organization trusts him/her or the other employees within the organization, when there is honesty between the working group members and when the employee benefits from the other employees within the team in order to achieve a team or organization goal (Dumitru, 2015). The lack of trust in the organizational environment and organizational relationships causes organizational commitment, human relations, organizational performance to decrease and occupational morale and product quality to decrease to low levels, resulting in increased occupational absenteeism and turnover rate (Halis et al., 2007). In the researches conducted under different conditions, it has been found that there is a repetitive and significant relationship between the trust level perceived by the workers and the level of organizational commitment, and that lack of trust decreased organizational commitment and this view has been supported (Lashari et al., 2016).

Trust can therefore be expressed as a valuable strategy for entrepreneurship. Another important concept today, where the concepts of innovation, competition and globalization are frequently used, is the entrepreneurship. As entrepreneurship increases in communities, new ideas and investments that create value also increase. Therefore, the entrepreneurship trainings are emphasized and formation of entrepreneurial intention in the individuals is encouraged. The creation of an organizational atmosphere in which trust is dominant plays an important role in terms of the entrepreneurial intention. Moghadam et al. (2013) found a significant relationship between interpersonal trust and entrepreneurship in non-executive employees and emphasized that the entrepreneurial intentions of individuals increase in proportion with the interpersonal trust and emphasized the importance of trust in terms of entrepreneurship. The most fundamental principle in this strategy is the development of a cooperative and trustworthy work environment among employees (Rostami et al., 2015). Contrary to what is known, entrepreneurship alone expresses more than the activity of people who create new business ideas. Entrepreneurship, which includes special skills, is a spirit, not just energy that is carried out once and then exhausted. Therefore, in this study, the ongoing entrepreneurial tendencies of Small and Medium Sized Enterprise (SME) managers who has previously been engaged in entrepreneurship and the effect of their trust to subordinates on these tendencies have been examined. Most of the previous hierarchical trust surveys have examined the trusts of subordinates to their superiors (Hassan et al., 2012). In this study, on the other hand, the trust of superiors to their subordinates has been examined. The conducted research is important in terms of examining the current entrepreneurial intention of the managers who have had entrepreneurship experience before, determining the level of trust to subordinate developed over time based on this work experience, predicting the importance of subordinate-superior relationship within the organizational climate in terms of entrepreneurship and contributing to the organizational behavior literature by exhibiting a study that has not been encountered in the literature before.

\section{Entrepreneurial Intention}

Increasing global competition, technological developments and changing market economies have increased interest in entrepreneurship all over the world (Ozaralli and Rivenburgh, 2016). Entrepreneurs differ from business managers who perform more or less routine tasks as individuals who direct their attention to realizing dynamic interventional activities. In order for a person to become an entrepreneur, s/he must have certain qualities such as being able to assume risks and responsibilities, a dynamic personality, openness to 
innovation, and a passion for growth (Kahya and Imamoğlu, 2015). There may be only one or more of these qualities in the individual, or none at all. Moreover, the presence of these qualifications is not enough to define the person as an entrepreneur. Entrepreneurship is a kind of behavioral feature that does not exist in every species and manifests in different forms. Because human behaviors consist of different elements and are influenced and shaped by these elements, (Dal, 2017). In literal sense, entrepreneur is a person or persons who define the opportunities as an individual or a team, putting forth the conditions and create the organization in line with the current opportunities and maintain it (Y1lmaz, 2014). Entrepreneurship is a process of creating a different value that involves obtaining individual satisfaction and economic prizes as a result of taking economic, physical and social risks by spending the necessary time and effort (Akpınar, 2011). Therefore, there are activities that create value at the foundation of the concept of entrepreneurship and allow career opportunities.

Entrepreneurship draws attention not only as a process that one provides and sustains one's own employment, but also as a process in which one determines his own career and develops according to the level and development of the enterprise (Sezer, 2013). As can be seen in Figure 1, the entrepreneurship process involves a person trying to find attractive opportunities, these opportunities developing usable job potential, and bringing together the resources and stakeholders to implement these plans (Valliere, 2015). This process includes planned and nontechnical behavior, which depends on the individual's desire, wishes, vision and ability to rationally assess the current conditions (Yanık et al., 2017). Therefore, in order for the entrepreneurship process to start, the individual must be inclined towards entrepreneurship or have entrepreneurial intention. Çelik et al. (2014) have defined the entrepreneurial intention as "the individual's thought of establishing a business and starting an enterprise that will help them make use of the surrounding potential opportunities rather than other career options" and Wibowo (2017) as "self-efficacy perceived by an individual as a result of evaluating his/her own skill to overcome problems and achieve success". Selfefficacy as a concept is the belief that one can successfully accomplish the behaviors necessary to achieve a certain goal, and this belief is usually shaped by successful behavior in the past (Buana, 2016). Entrepreneurial self-efficacy is based on the belief of the individual that towards the characteristics of entrepreneurship that he or she thinks he has (Kerse et al., 2017). Self-sufficiency stands out as problem solving, decision making, creativity, credibility and leadership skills in a person (Wibowo, 2017). The development of self-confidence and self-efficacy perception plays an important role in increasing one's tendency to become an entrepreneur and in having tolerance against uncertainty (Alparslan and Özmen, 2017). In the case of low self-sufficiency, it causes intimidation in the individuals upon encountering a difficulty and the thought that all the efforts are useless (Buana, 2016). Therefore, selfefficacy is very important in terms of entrepreneurship because of its strong abilities. 


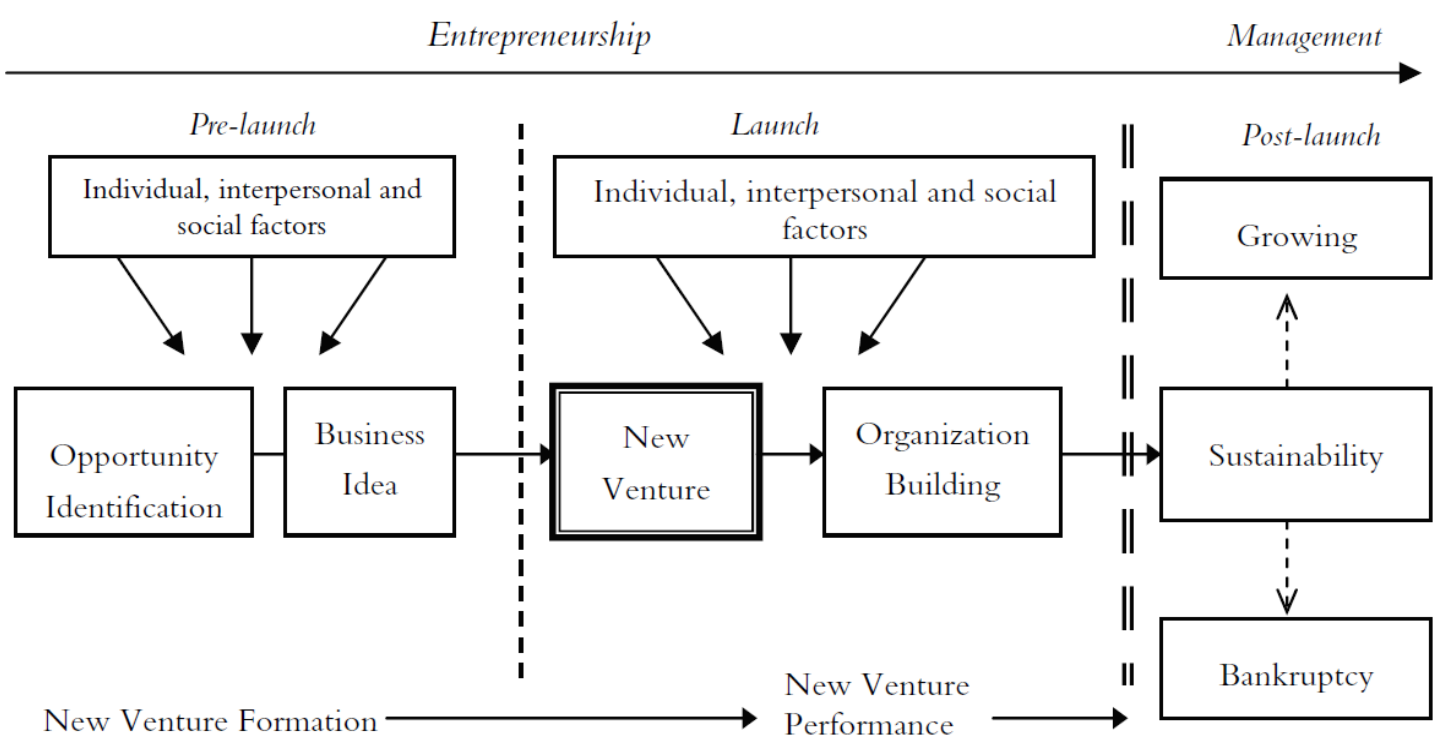

Figure 1: Entrepreneurship Process

Source: Moriano, J. A., Zarnowska, A., \& Palací, F. J. (2007). Entrepreneurship as a process. In J. A. M. L. a. M. Gorgievski (Ed.), Psychology of Entrepreneurship Research and Education. Madrid: Universidad Nacional de Educación a Distancia.

It has been stated in the literature that many factors are effective on entrepreneurial intention. Bozkurt (2014) argued that the person possessing entrepreneurial characteristics is not sufficient in the formation of the entrepreneurship and it is also required to support the person sufficiently. Marangoz (2008) has stated that entrepreneurs are products of the socioeconomic environment they live in and although they are concerned with individual ability and education of the person, organizational culture and environmental factors also affect the behavior and decisions of the entrepreneur and that factors affecting entrepreneurship are culture and education, family and social environment, psychological factors, legal, political and administrative factors, financial environment and religious factors. Similarly, Paço et al. (2015) gave stated that the economic and socio-cultural environment of a person directly affects the entrepreneurial intention and entrepreneurial commitment. Balli and Koca Ball1 (2014) have stated that the most important source of motivation in the entrepreneurial intention is the need to succeed. Shneor and Jenssen (2014) have pointed out that the formation of entrepreneurial intentions is an important source of human capital and social capital. In the human capital, education and experience that improve the cognitive abilities of a person are at the forefront. In social capital, family, colleagues and personal environment factors provide important guidance when planning for an enterprise. Approaching to the formation of the entrepreneurial intention, Ensari and Alay (2017) have listed the psychological factors considered to be effective on entrepreneurship potential as selfconfidence, tendency to take risks, extroversion, need to succeed, focus of control and desire for independence. From a different perspective, Al-Harrasi et al. (2014) have found that there are four main factors affecting the entrepreneurial intention, i.e. factors related to personality traits, contextual factors, motivational factors, and factors related to personal infrastructure. Supporting this view, Kerse et al. (2017) have noted that certain personal characteristics that individuals possess are the key to becoming entrepreneurs. Młokosiewicz and Misiak-Kwit (2017) have argued that positive norms and values are among the factors that influence entrepreneurship.

\section{Trust in Managerial Relationship}

In organizational sense, trust has been defined as "a psychological occasion based on the expectations realized in relation to the behaviors of other employees in the organization" 
by Rua and Araujo (2016); as "the effort of an organization to act in goodwill in its activities, the employees' being honest in their mutual interactions and activities and not acting in an opportunist and abusive manner" by Bağc1 and Akbaş and as "the trust of employees in the management and the level of their beliefs in what they are told by the management" by Şimşek and Taşçı (2014). There is various trust dimensions used in different studies in the organizational field in the literature. Many dimensions such as openness, trustworthiness, dependency and employee involvement are among organizational trust dimensions (İbrahimoğlu et al., 2011). According to another source, there are two aspects of organizational trust. The first of these trust of the managers' in their own competence and trust in the employees in carrying out the business; second is the trust based on honesty, justice, sincerity and good manners that employees feel in the expressions of the managers (Uslu and Oklay, 2015). Tokgöz and Seymen (2013) divided the trust into five classes, being past-based trust, trust gained through the third parties, category-based trust, role-based trust and rulebased trust. Yilmaz and Sünbül (2009) have examined trust in two dimensions, being trust in the person being managed and trust in the person managing. Zaheer et al. (1998) focused on inter-organizational trust and interpersonal trust and defined the inter-organizational trust as "the extent of trust placed in the partner organization by the members of a focal organization" and interpersonal trust as "the extent of a boundary-spanning agent's trust in her counterpart in the partner organization". Upon a general evaluation, it can be said that the studies have been integrated in three fundamental trust dimensions, being trust in the organization, interpersonal trust and trust in the manager.

Mutual trust is the preference of the individual to choose being defenseless in the organization worked in, interpersonal trust for the superior to subordinate or subordinate to vertical organization and trust in the manager to choose against vertical hierarchy. Conceptually, organizations do not really trust each other, trust is mainly seen on one side or on both sides among the persons (MacDuffie, 2011). Therefore, trust in the organization is oriented to social targets, whereas personal trust includes face-to-face relationships among employees (Rusu and Baboş, 2016). Trust in organizations also has a risk of potential doubt, although it is an important sense for employees have in terms of social relationships of the employees (Lewis and Weigert, 1985). Therefore, interpersonal trust, which has an important place in the interaction with competitors, partners and friends, expresses acceptance of this risk in the context of another person's behavior (Borum, 2010). With the acceptance of this risk in organizations, interpersonal relations and the level of trust in these relationships are very important in terms of efficiency, compatibility and continuity. Employees in the atmosphere of the organization feel the need to work towards their mutual trust in order to provide high quality, efficiency and effectiveness with their managers, colleagues and their institutions (Örücü and Kanbur, 2017).

According to the trusting nature as expressed in Figure 2, employees feel more confident when confronted with positive outcomes, and sense of insecurity begins when they achieve negative outcomes (Dromereschi and Cuza, 2010). In organizations, as managers trust the employees, the employees respond to this as trust in the management. However, if there is insecurity about the employees in the structure of the organization, and this insecurity is perceived by the employees, a sense of insecurity naturally develops in the employees towards the organization and management (Singh and Srivastava, 2016). Therefore, it is quite natural that the interpersonal trust, which is a feeling of social reality and difficult to explain by individual psychology, to manifest in the working groups (Lewis and Weigert, 1985). High trust is an important requirement, as most associations are thought to be formed by working groups. Because, in these organization, more responsibility and authority are given to the lower levels of the organization and an optimal working environment is provided based on 
team work based and flexible understanding (Y1lmaz, 2005). It is necessary to maintain continuity between the trusting parties in order not to disturb this environment. Interpersonal trust (Hassan et al., 2012), which is expressed as a type of hierarchical trust that focuses on risk in relation to the subordinate-superior relationship, is considered to be an important factor in increasing organizational commitment and thus increasing organizational effectiveness of employees in organizations (Paliszkiewicz, 2011).

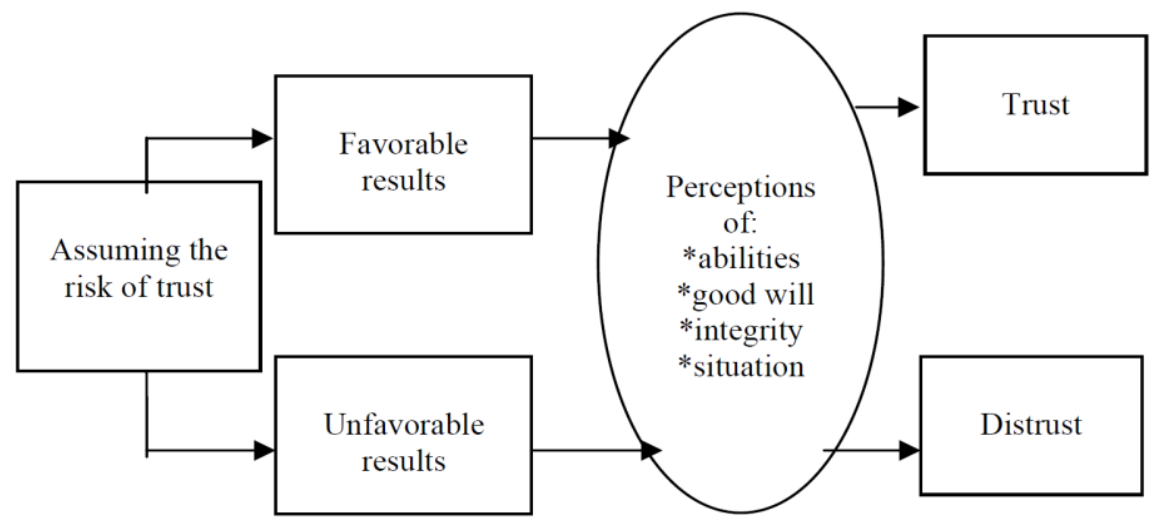

Figure 2: The Moderators of Trust

Source: Mayer, R. C., Davis, J. H., \& Schoorman, F. D. (1995). An Integration Model of Organizational Trust. The Academy of Management Review, 20(3), 709-835.

The mood and emotions play an important role in the process of creating the first impression that is effective for the development of relationships and trust among people (Blomqvist and Ståhle, 2000). Unless there is reciprocal and reasonable confidence in the individuals involved in the interaction during the first impression, it is not possible for the interpersonal trust to increase as individuals see each other extremely anxious and they are reluctant to take risks (Simpson, 2007). Therefore, in order to create interpersonal trust in the organizations, it is required that the occasions causing lack of trusts are eliminated, the individuals carry out actions that will regularly evoke positive feelings, both individuals carry out the actions that will at least not be perceived as negative upon discontent and organizational policies must promote a mutual understanding between the employees (Paliszkiewicz, 2011).

\section{Material and Method}

\section{The Purpose of the Research}

Previous researches have not examined what kind of effect the management experience gained after the entrepreneurship activity has on the entrepreneurship approach of the individuals. Therefore, the purpose of this research which is conducted considering the entrepreneurship experience, is to determine the entrepreneurial intention and trust levels of the individuals' who have conducted entrepreneurship activities in the past and of individuals working as managers in SMEs still connected to this activity towards subordinates, determine whether there is a significant relationship between these levels and if there is, investigate the effect of the manager's trust to subordinate on the entrepreneurial intention and determine the roles of gender and entrepreneurial training on this effect.

\section{The Population and Sample of the Research}

The population of research consists of all SME managers in Turkey. The sample of the research consists of the SME managers who operate in Zonguldak and participated in the research. In the study, purposeful sampling method among non-probability sampling methods has been used and data has been obtained from 316 individuals within the scope of the 
research implemented in the same time frame, however, the surveys responded by 12 managers who give different answers to cross questions have been excluded from the assessment and a sample volume consisting of 304 individuals has been obtained. $63.2 \%$ of the sample consists of male managers and $36.8 \%$ consists of female managers. In the sample, $81.5 \%$ of the managers are in the age range of $21-50$ years and only $28.7 \%$ are university graduates.

\section{The Data Collection Method of the Research}

The data to be used in the research have been obtained from the SMEs managers via the face-to-face survey method. The survey used in the research consists of two dimensions; entrepreneurial intention and trust in subordinate. Information on these scales is given below.

Entrepreneurship Intention Scale:Developed by Y1lmaz and Sünbül (2009), the scale consists of 36 items of 5-Likert type. The scale was developed by the authors and subjected to validity and reliability analyzes and it has been determined that factor loadings in the measure are collected in one factor and Cronbach Alpha value is 0,900.

Trust in Subordinate Scale: Trust scales developed by Roberts and O'Reilly (1974) and Korsgaard et al. (1995) have been examined by Küskü (1999) and 6 items out of these scales have been used. Küskü (1999) has added 4 items in addition to these items and developed a 10-item 5-Likert-type "Trust in the Person Being Managed". As a result of explanatory factor analysis for this scale, it has been found that three factors, achieving organizational tasks, taking risks on decisions and solving problems, are generated.

\section{The Research Model and Hypotheses}

Scanning model has been used in the research. The dependent variable of the research is the entrepreneurial intention, main independent variable is trust in subordinate, subindependent variables are trust in subordinates for achieving organizational tasks, for taking risks on decisions and troubleshooting.

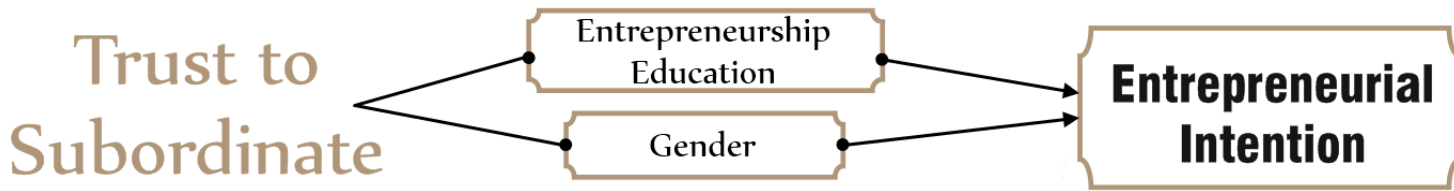

* Achievement of Organizational Tasks

* Taking Risks About Decisions

${ }^{*}$ Troubleshooting

Figure 3: Conceptual Model of the Research

\section{Hypotheses of the Research;}

$\mathbf{H}_{1 \mathbf{a}}$ : There is a significant relationship between trust in subordinate and managers' entrepreneurial intention.

$\mathbf{H}_{1 \mathrm{~b}}$ : The entrepreneurial intention increases as the trust in subordinates for achieving organizational tasks increases.

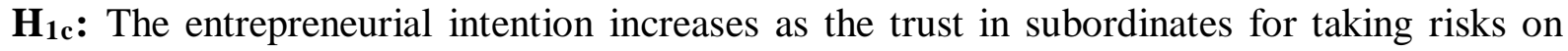
decisions increases.

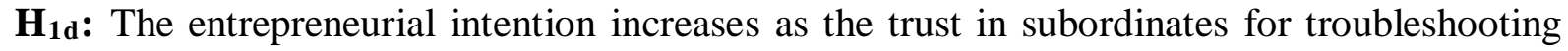
increases. 


\section{Research Data Analysis}

SPSS 20.0 (Statistical Package for Social Sciences) software has been used to evaluate the data obtained through the research. Confirmatory Factor Analysis has been used to determine the structural validity of the scales used in the research, reliability analysis for the determination of the internal consistency of the scales, frequency analysis for the descriptive statistics, correlation analysis to determine the relationship and severity of the relationship between dependent and independent variables and multiple regression analysis to examine the relationship between variables.

\section{Findings}

Confirmatory Factor Analysis (CFA) has been performed to determine the construct validity of the scales used in the research. The compliance values obtained and suggested as a result of implementing Confirmatory Factor Analysis to "Entrepreneurial Intention" scale consisting of 36 items have been expressed in Table 1 and the compliance values obtained and suggested from the "Trust in the Person Being Managed" scale consisting of 10 items in Table 2 .

Table 1: Entrepreneurship Intention Scale - Compliance Values

\begin{tabular}{lccccccccc}
\hline Compliance Criteria & $\chi^{2}$ & $\mathbf{p}$ & $\chi^{\mathbf{2} / \mathbf{d f}}$ & RMSEA & CFI & IFI & SRMR & NFI & GFI \\
\hline $\begin{array}{l}\text { Suggested Compliance } \\
\text { Values }\end{array}$ & 610.891 & 0.001 & 1.441 & 0.037 & 0.969 & 0.970 & 0.051 & 0.908 & 0.900 \\
\hline
\end{tabular}

Upon examining Table 1: it is observed that the value of the chi-square is $610.891 ; \mathrm{p}$ value is 0.001 ; RMSEA value is 0.037 ; GFI value is 0.900 ; CFI value is 0.969 , IFI value is 0.970 ; NFI value is 0.908 , chi-square/degree of freedom is 1.441 and SRMR value is 0.051 .

Table 2: Trust to Subordinate Scale - Compliance Values

\begin{tabular}{lccccccccc}
\hline Compliance Criteria & $\chi^{2}$ & $\mathbf{p}$ & $\chi^{2} / \mathbf{d f}$ & RMSEA & CFI & IFI & SRMR & NFI & GFI \\
\hline $\begin{array}{l}\text { Suggested Compliance } \\
\text { Values }\end{array}$ & 57.617 & 0.014 & 2.401 & 0.065 & 0.987 & 0.987 & 0.017 & 0.979 & 0.965 \\
\hline
\end{tabular}

Upon examining Table 2: it is observed that the value of the chi-square is $57.617 ; \mathrm{p}$ value is 0.014 ; RMSEA value is 0.065 ; GFI value is 0.965 ; CFI value is 0.987 , IFI value is 0.987; NFI value is 0.979, chi-square/degree of freedom is 2.401 and SRMR value is 0.017 . The compliance values suggested for the entrepreneurial intention scale exhibited in Table 1 and for the trust in subordinate scale exhibited in Table 2 have been found to be in accordance with the goodness of fit statistics published by Schermelleh-Engel et al. (2003).

Table 3 shows the results of the reliability analysis for the scales for which structural validity is obtained as a result of the Confirmatory Factor Analysis. As a result of the analyzes, Cronbach's Alpha coefficient has been determined to be 0.946 for entrepreneurial intention scale and 0.942 for trust in subordinate scale. These obtained values indicate that the scales used in the research have high internal consistency.

Table 3: Reliability Analysis

\begin{tabular}{lcc}
\hline & Cronbach's Alpha & N of Items \\
\hline Entrepreneurship Intention Scale & 0.946 & 34 \\
Trust in SubordinateScale & 0.942 & 9 \\
\hline
\end{tabular}

Table 4 provides the results of the correlation analysis between the dependent variable main independent variable and independent sub-variables of the research. According to this table, a significant and positive relationship at a moderate level has been determined between the independent variable managers' entrepreneurial intention and main independent variable 
trust in subordinate and between the entrepreneurial intention and sub-independent variables achieving organizational tasks, taking risks on decisions and troubleshooting.

Table 4: Correlation Analysis

Entrepreneurial Intention

\begin{tabular}{clc}
\hline \multirow{2}{*}{ Trust in Subordinate } & Pearson Correlation & $\mathbf{0 . 4 5 5}$ \\
& Sig. (2-tailed) & 0.001 \\
\hline * Achievement of & Pearson Correlation & $\mathbf{0 . 4 2 2}$ \\
Organizational Tasks & Sig. (2-tailed) & 0.001 \\
\hline \multirow{2}{*}{ * Taking Risks on Decisions } & Pearson Correlation & $\mathbf{0 . 4 2 2}$ \\
& Sig. (2-tailed) & 0.001 \\
\hline \multirow{2}{*}{ * Troubleshooting } & Pearson Correlation & $\mathbf{0 . 4 4 2}$ \\
& Sig. (2-tailed) & 0.001 \\
\hline
\end{tabular}

Table 5 shows the multiple regression analysis conducted on whole sample regarding the relationship between entrepreneurial intention and trust in subordinate. Upon examining the results of the regression analysis conducted by using the Stepwise method, it has been found that the regression model to be established indicates statistical significance, since the statistical significance value is lower than 0.05 .

Table 5: Regression - ANOVA

\begin{tabular}{lccccc}
\hline & & Sum of Squares & Mean Square & F & Sig. \\
\hline \multirow{3}{*}{ Entrepreneurial Intention } & Regression & 4117.496 & 4117.496 & & \\
& Residual & 3091.932 & 19.446 & 211.739 & 0.000 \\
& Total & 7209.429 & & & \\
\hline
\end{tabular}

The model summary of the multiple regression analysis performed is shown in Table 6. According to the results of the analysis, it has been found that $20.1 \%$ of the change in entrepreneurial intentions has been explained by the change in the trust of SME managers in the subordinates for troubleshooting and achieving organizational tasks. When the generated model is examined, the value that the managers' entrepreneurial intention can take can be formulated as follows;

"Entrepreneurial Intention $=111.283+(1.753 \times$ Trust in Subordinates for

Troubleshooting $)+(0.819 \times$ Trust in Subordinates for Achieving Organizational Tasks $)$

Table 6: Regression - Model Summary

\begin{tabular}{|c|c|c|c|c|c|c|}
\hline & & $\beta$ & $\mathbf{t}$ & Sig. & $\mathbf{R}^{2}$ & Adjusted $\mathbf{R}^{2}$ \\
\hline \multirow{3}{*}{$\begin{array}{l}\text { Entrepreneurial } \\
\text { Intention }\end{array}$} & Constant & 111.283 & 27.792 & 0.000 & \multirow{3}{*}{0.209} & \multirow{3}{*}{0.201} \\
\hline & Troubleshooting & 1.753 & 3.266 & 0.001 & & \\
\hline & $\begin{array}{l}\text { Achievement of } \\
\text { Organizational Tasks }\end{array}$ & 0.819 & 2.019 & 0.044 & & \\
\hline
\end{tabular}

According to the regression model created, it has been determined that a 1-unit increase in the trust in subordinates for troubleshooting causes an increase of 1.753 units on the managers' entrepreneurial intention and a 1-unit increase in the trust in employees for achieving organizational tasks causes an increase of 0.819 units on managers' entrepreneurial intention.

Table 7 shows the results of gender-based regression analysis conducted on the relationship between entrepreneurial intention and trust in subordinate. When the analyzes conducted using the Stepwise method are examined, it is determined that the regression models to be established express statistical significance. 
Table 7: Regression - ANOVA

\begin{tabular}{cccccc}
\hline & & Sum of Squares & Mean Square & F & Sig. \\
\hline \multirow{3}{*}{ Male Manager } & Regression & 9997.407 & 9997.407 & & \\
& Residual & 36634.462 & 192.813 & 51.850 & 0.000 \\
& Total & 46631.870 & & & \\
\hline \multirow{3}{*}{ Female Manager } & Regression & 9043.527 & 9043.527 & & 0.000 \\
& Residual & 27691.580 & 251.742 & 35.924 & \\
& Total & 36735.107 & & &
\end{tabular}

The model summary of the multiple regression analyses performed is shown in Table 8. According to the results of this analysis, $21 \%$ of the change in the male managers' entrepreneurial intention has been explained by the change in the trust in subordinates for troubleshooting and $23.9 \%$ of the change in the female managers' entrepreneurial intention has been explained by the change in the trust in subordinates for achieving organizational tasks.

Table 8: Regression - Model Summary

\begin{tabular}{clccccc}
\hline & & $\boldsymbol{\beta}$ & $\mathbf{t}$ & Sig. & $\mathbf{R}^{\mathbf{2}}$ & Adjusted $\mathbf{R}^{\mathbf{2}}$ \\
\hline \multirow{2}{*}{ Male Manager } & Constant & 115.473 & 27.188 & 0.000 & \multirow{2}{*}{0.214} & \multirow{2}{*}{0.210} \\
& Troubleshooting & 2.482 & 7.201 & 0.000 & & \\
\hline \multirow{2}{*}{ Female Manager } & Constant & 101.572 & 13.191 & 0.000 & & \\
& $\begin{array}{l}\text { Achievement of } \\
\text { Organizational Tasks }\end{array}$ & 2.730 & 5.994 & 0.000 & 0.243 & 0.239 \\
& & & & &
\end{tabular}

Upon examining the created model, the values that male and female managers' entrepreneurial intention can take are formulated in Table 9.

Table 9: Regression Formulas

$\begin{array}{ll}\text { For Male Manager; } & \begin{array}{l}\text { Entrepreneurial Intention }=115.473+(2.482 \times \text { Trust in Subordinates for } \\ \text { Troubleshooting })\end{array}\end{array}$

For Female Manager; $\quad$ Entrepreneurial Intention $=101.572+(2.730 \times$ Trust in Subordinates for

Achieving Organizational Tasks)

According to the regression models created, it has been determined that a 1-unit increase in the trust in subordinates for troubleshooting causes an increase of 2.482 units on the male managers' entrepreneurial intention and a 1-unit increase in the trust in subordinates for achieving organizational tasks causes an increase of 2.730 units on female managers' entrepreneurial intention.

The regression analysis results for the relationship between entrepreneurial intention and trust in subordinate, based on whether or not SME managers have previously had an entrepreneurial training, are shown in Table 10. When the analyzes conducted using the Stepwise method is examined, it is determined that the regression models to be established express statistical significance. 
Table 10: Regression - ANOVA

\begin{tabular}{cccccc}
\hline & & Sum of Squares & Mean Square & F & Sig. \\
\hline $\begin{array}{c}\text { Managers who have } \\
\text { received }\end{array}$ & Regression & 1463.391 & 1463.391 & & 0.005 \\
entrepreneurial training & Residual & 3876.683 & 155.067 & 9.437 & \\
\hline Managers who have & Total & 5340.074 & & & 0.000 \\
$\begin{array}{c}\text { received } \\
\text { not received }\end{array}$ & Regression & 15675.394 & 7837.697 & 34.597 \\
entrepreneurial training & Residual & 62072.844 & 226.543 & & \\
\hline
\end{tabular}

The model summary of the multiple regression analyses performed is shown in Table 11. According to the results of this analysis; it has been determined that $24.4 \%$ of the change in the entrepreneurial intention of the managers who have received entrepreneurial training is explained by the change in the trust to employees for achieving organizational tasks and $19.6 \%$ of the change in the entrepreneurial intention of the managers who have not received entrepreneurial training was explained by the change in the trust in employees for troubleshooting and taking risks on decisions.

Table 11: Regression - Model Summary

\begin{tabular}{|c|c|c|c|c|c|c|}
\hline & & $\beta$ & $\mathbf{t}$ & Sig. & $\mathbf{R}^{2}$ & Adjusted $\mathbf{R}^{2}$ \\
\hline \multirow{2}{*}{$\begin{array}{c}\text { Managers who have } \\
\text { received } \\
\text { entrepreneurial training }\end{array}$} & Constant & 115.935 & 13.237 & 0.000 & \multirow[b]{2}{*}{0.274} & \multirow[b]{2}{*}{0.244} \\
\hline & $\begin{array}{l}\text { Achievement of } \\
\text { Organizational Tasks }\end{array}$ & 1.765 & 3.072 & 0.005 & & \\
\hline \multirow{3}{*}{$\begin{array}{c}\text { Managers who have } \\
\text { received } \\
\text { not received } \\
\text { entrepreneurial training }\end{array}$} & Constant & 111.231 & 25.817 & 0.000 & \multirow{3}{*}{0.202} & \multirow{3}{*}{0.196} \\
\hline & Troubleshooting & 1.728 & 2.908 & 0.004 & & \\
\hline & Taking Risks on Decisions & 1.682 & 2.017 & 0.045 & & \\
\hline
\end{tabular}

Upon examining the created model, the values that entrepreneurial intention of the managers who have and have not received entrepreneurial training before can take are formulated in Table 12.

Table 12: Regression Formulas

$\begin{aligned} \begin{array}{r}\text { For Managers who have } \\ \text { received entrepreneurial } \\ \text { training; }\end{array} & \begin{array}{l}\text { Entrepreneurial Intention }=115.935+(1.765 \times \text { Trust in Subordinates for } \\ \text { Achieving Organizational Tasks })\end{array} \\ \begin{aligned} \text { For Managers who have } \\ \text { not received }\end{aligned} & \begin{array}{l}\text { Entrepreneurial Intention }=111.231+(1.728 \times \text { Trust in Subordinates for } \\ \text { Troubleshooting })+(1.682 \times \text { Trust in Subordinates for Taking Risks on }\end{array} \\ \text { entrepreneurial training; } & \text { Decisions })\end{aligned}$

According to the regression models created; it has been determined that a 1-unit increase in trust to subordinates for achieving organizational tasks causes an increase of 1.765 units in entrepreneurial intention of the managers who have received entrepreneurial training, a 1-unit increase in the trust in subordinates for troubleshooting causes an increase of 1.728 units in entrepreneurial intention of the managers who have not received entrepreneurial training and that a 1-unit increase in the trust in subordinates for taking risks on decisions causes an increase of 1.682 units on the entrepreneurial intention of the managers who have not received entrepreneurial training.

\section{Conclusions and Recommendations}

The level of trust in subordinates of SME managers with entrepreneurial experience has been determined by the research conducted and whether this level of confidence is 
influenced by the entrepreneurial intention is examined. In this context, data has been obtained from 304 SME managers via survey method. The obtained data has been processed with SPSS 20.0 program and as a result of the analyzes performed, a positive and statistically significant relationship has been found between level of trust in subordinate by the SME managers and entrepreneurial intention and the three sub-dimensions of the trust in subordinate and entrepreneurial intention. As a result of the multiple regression analyzes performed; when all managers are examined, it has been determined that a model can be established between the troubleshooting and achieving organizational tasks dimensions of the level of trust to subordinate and entrepreneurial intention, which explains $20.1 \%$ of the change in entrepreneurial intention and that 1-unit increase in trust to employees for troubleshooting leads to an increase of 1.753 units in managers' entrepreneurial intention, 1-unit increase in the trust to employees for achieving organizational tasks has been found to be caused by the increase of 0.819 units on the entrepreneurship intention of the managers. As a result of the multiple regression analysis conducted by segregating the manager data by gender, it has been determined that a model can be established between only the troubleshooting dimension of level of trust in subordinate for male managers and the entrepreneurial intention and a 1-unit increase in the trust in subordinates for troubleshooting causes an increase of 2.482 units on the male managers' entrepreneurial intention. For female managers, it has been determined that a model can be established between only achieving organizational tasks dimension of the level of trust in subordinate and entrepreneurial intention and that 1-unit increase in the trust in subordinates for achieving organizational tasks causes an increase of 2.760 units on female managers' entrepreneurial intention. When the relationship between the trust in subordinate and entrepreneurial intention is differentiated based on whether entrepreneurial training is received, it has been determined that a model can be established between the achieving organizational tasks dimension of the level of trust in subordinate for managers who have received entrepreneurial training and entrepreneurial intention and that 1 -unit increase in the trust in subordinates for achieving organizational tasks causes an increase of 1.765 units on entrepreneurial intention of the managers who have received entrepreneurial training. For the managers who have not received entrepreneurial training, it has been determined that a model can be established between the troubleshooting and taking risks on decisions dimensions of the level of trust in subordinate and the entrepreneurial intention and that a 1-unit increase in the trust in subordinates for troubleshooting causes an increase of 1.728 units and a 1-unit increase in the trust in subordinates for taking risks on decisions causes an increase of 1.682 units on the entrepreneurial intention of the managers who have not received entrepreneurial training.

When the results obtained from the research are evaluated without any distinction in the sample, it has been observed that the subordinates being capable of solving problems while the manager is absent and that maintaining the success of the management by successfully performing the work of the associations increase the enthusiasm of the SME managers in entrepreneurial activity to a considerable extent. Subordinates taking risks on decision does not have any significant effect on enthusiasm. However, when the SME managers have been evaluated on a gender basis, different results have been obtained. It has been determined that it is sufficient for male managers to see that subordinates can solve problems in order to increase entrepreneurial intention. It has been determined that, for female managers, subordinates' solving problems do not have a meaningful effect and subordinates' successfully running the organizational tasks is sufficient for the entrepreneurial intention. When evaluated in this respect, gender has been found to be an important factor that made a difference between trust in subordinate and entrepreneurial intention. Another factor that causes differences in research outside gender is entrepreneurial training. Successful execution of organizational tasks by subordinates for the continuity of entrepreneurship in 
entrepreneurship-trained SME managers has been identified as an important element. For the SME managers who have not received entrepreneurial training, it has been found that the subordinates' capability for troubleshooting and trust to the subordinates' decisions are more significant. It is understood with these results that entrepreneurs should interact with the employees in the organization in the best way possible. In order to be able to trust subordinates or for the subordinates to perform successful works to the extent that they can be trusted, subordinates must trust the managers first. This can only be achieved by supporting subordinates in management activities within the organization, motivating them, ensuring their job security, ensuring that their salaries are paid at a satisfactory level and on time, ensuring occupational safety, lack of conflict, minimizing employee turnover rate, giving education support, high level of perception of justice, giving them ability to join the decisions and adhering to the psychological contract. It is unrealistic to expect subordinates to exhibit behaviors that can be trusted in the management approach in which these approaches are not adopted.

Studies in the literature often measure entrepreneurial intentions of students or independent individuals. These researches are important for the enrichment of the entrepreneurship literature and for the popularization of entrepreneurship education but the examination of the organizational dimension of entrepreneurship have also been considered necessary for organizational behavior. Therefore, the research has been established on SME managers who had entrepreneurial experience, and the relationship between managers and subordinates has been examined in the atmosphere of the organization and trust in subordinates has been emphasized. The ultimate conclusion in this research is that the managerial experience gained after entrepreneurial activity has a very significant effect on the willingness to continue entrepreneurial activity and to be in new enterprises in the future. Therefore, in order to be able to increase entrepreneurship in macro-terms, the necessity of examining entrepreneurship not only before the entrepreneurship but also after it has emerged. Given the continuity of entrepreneurship expressed as a soul, it is important that managers' attitudes in the organization and their interaction with employees after entrepreneurship are examined. This study has only examined the attitude of trust in subordinate. It is suggested for the researches to be made in the future that the entrepreneurial intention be integrated further with the organizational behavior and the effects of the working psychology on the entrepreneurship be detailed.

\section{References}

Akpınar, S. (2011). Girişimciliğin temel kavramları. Umuttepe Yayınları, Kocaeli.

Al-Harrasi, A. S., Al-Zadjali, E. B., \& Al-Salti, Z. S. (2014). Factors impacting entrepreneurial intention: a literature review. International Journal of Social, Management, Economics and Business Engineering, 8(8), 2438-2441.

Alparslan, A. M., \& Özmen, M. (2017). Kişisel değerlerin girişimcilik eğilimine etkisi: demografik özelliklerin rolü. Insan ve Toplum Bilimleri Araştırmaları Dergisi,6(2), 957-976.

Bağcı, Z., \& Akbaş, T. T. (2016). Hemşirelerin örgütsel güven algılarının örgütsel bağlılıkları üzerindeki etkisini belirlemeye yönelik bir araştırma. Manas Sosyal Araştırmalar Dergisi,5(5), 155-170.

Ballı, E., \& Koca Ballı, A. İ. (2014). Üniversite öğrencilerinin bireysel değerleri ve girişimcilik eğilimleri. Çukurova Üniversitesi İktisadi ve İdari Bilimler Fakültesi Dergisi, 18(1), 101-121. 
Bat1, G. F., \& Tutar, E. (2016). Örgütsel güven kavramı, özellikleri ve yararlar1. ArelEysad,1(2), 35-41.

Blomqvist, K., \& Ståhle, P. (2000). Building organizational trust. In 16th Annual IMP Conference, Bath, UK.

Borum, R. (2010). The science of interpersonal trust. Mental Health Law \& Policy Faculty Publications.

Bozkurt, Ö. Ç. (2014). Planlanmış davranış teorisi çerçevesinde öğrencilerin girişimci olma niyetlerinin incelenmesi. Ekonomi ve Yönetim Araştırmaları Dergisi,3(1), 27-47.

Buana, Y. (2016). Mapping the phenomenon of students' Entrepreneurial Intention. Binus Business Review,7(2), 117-123.

Çelik, A., İnce, M., \& Bozyiğit, S. (2014). Üniversite öğrencilerinin girişimcilik niyetlerini etkileyen ailesel faktörleri belirlemeye yönelik bir çalışma. Niğde Üniversitesi İktisadi ve İdari Bilimler Fakültesi Dergisi,7(3), 113-124.

Dal, M. (2017). Üniversite öğrencilerinin girişimcilik algılarının analizi: Iğdır üniversitesi örneği. Researcher: Social Science Studies,5(4), 521-531.

Dromereschi, M. I., \& Cuza, Al. I. (2010). Organizational trust or beyond appearances. Studies and Scientific Researches - Economic Edition, 15, 351-359.

Dumitru, C. D. (2015). Predictors of organizational trust: the dynamic relationship between organizational trust, organizational identification and cultural intelligence. International Conference on Marketing and Business Development Journal,1(1), 161167.

Ensari, M. Ş., \& Alay, H. K. (2017). Üniversite öğrencilerinin yenilikçilik eğilimi ile girişimcilik potansiyelleri arasındaki ilişkiye ailelerin girişimcilik öyküsünün aracı etkisinin incelenmesi üzerine bir araştırma. Pamukkale Üniversitesi Sosyal Bilimler Enstitüsü Dergisi,28, 235-248.

Halis, M., Gökgöz, G. S., \& Yaşar, Ö. (2007). Örgütsel güvenin belirleyici faktörleri ve bankacılık sektöründe bir uygulama. MANAS Sosyal Bilimler Dergisi, 17, 187-205.

Hassan, M., Toylan, N. V., Semerciöz, F., \& Aksel, I. (2012). Interpersonal trust and its role in organizations. International Business Research, 5(8), 33-39.

İbrahimoğlu, N., Uğurlu, Ö. Y., \& Kızıloğlu, M. (2011). Örgütlerde mentorlüğün örgütsel güven algısına etkisine ilişkin bir araştırma. Ç.Ü. Sosyal Bilimler Enstitüsü Dergisi,20(3), 297-318.

Kahya, C., \& İmamoğlu, İ. K. (2015). Ekonomi okuryazarlığının girişimcilik niyeti üzerindeki rolü. The Journal of Academic Social Science Studies,39, 139-156.

Kerse, G., Babadağ, M., \& Kerse, Y. (2017). Girişimcilik eğitiminin girişimcilik niyetine etkisi: girişimsel öz-yetkinliğin aracı rolü. Süleyman Demirel Üniversitesi Sosyal Bilimler Enstitüsü Dergisi,4(29), 633-656.

Korsgaard, M. A., \& Roberson, L. (1995). Procedural justice in performance evaluation: the role of instrumental and non-instrumental voice in performance appraisal discussions. Journal of Management, 21(4), 60-84.

Küskü, F. (1999). Yöneten - Yönetilen ilişkisinde güven: Ampirik Bir İnceleme. Amme Iddaresi Dergisi,32(1), 135-151. 
Lashari, M., Moazzam, A., Salman, Y., \& Irfan, S. (2016). Impact of organizational trust on organizational justice and organizational commitment: a case of university of sargodha. Journal of the Research Society of Pakistan, 53(2), 170-194.

Lewis, J. D., \& Weigert, A. (1985). Trust as a social reality. Social Forces,63(4), 967-985.

MacDuffie, J. P. (2011). Inter-organizational trust and the dynamics of distrust. Journal of International Business Studies, 42, 35-47.

Marangoz, M. (2008). Girişimcilik. Çanakkale: Pozitif Matbaacılık.

Mayer, R. C., Davis, J. H., \& Schoorman, F. D. (1995). An integration model of organizational trust. The Academy of Management Review Briarcliff Manor, 20(3), 709-835.

Młokosiewicz, M., \& Misiak-Kwit, S. (2017). the 1mpact of trust on entrepreneurship in poland. Journal of Entrepreneurship, Management and Innovation, 13(4), 79-95.

Moghadam, S. K., Zavari, M. E., Enayati, G., \& Lari, M. T. (2013). Examination of the relationships among organizational trust, organizational learning and entrepreneurship in SMEs. World Applied Sciences Journal,27(9), 1134-1145.

Moriano, J. A., Zarnowska, A., \& Palací, F. J. (2007). Entrepreneurship as a process. In J. A. M. L. a. M. Gorgievski (Ed.), Psychology of Entrepreneurship Research and Education. madrid: Universidad Nacional de Educación a Distancia.

Ozaralli, N., \& Rivenburgh, N. K. (2016). Entrepreneurial intention: antecedents to entrepreneurial behavior in the U.S.A. and Turkey. Journal of Global Entrepreneurship Research,6(3), 1-32.

Örücü, E., \& Kanbur, A. (2017). Otel çalışanlarında örgütsel sessizlik ve örgütsel güven ilişkisi: Bandırma ilçesi örneği. Uluslararası Sosyal Araştırmalar Dergisi,10(52), 1109-1123.

Paço, A., Ferreira, J. M., Raposo, M., Rodrigues, R. G., \& Dinis, A. (2015). Entrepreneurial intentions: is education enough?. International Entrepreneurship and Management Journal,11(1), 57-75.

Paliszkiewicz, J. O. (2011). Trust management: literature review. Management, 6(4), 315331.

Roberts, K. H., \& O'Reilly, C. A. (1974). Measuring organizational communication. Journal of Applied Psychology, 59(3), 321-326.

Rostami, N. A., Shad, F. S., \& Etemadifar, E. (2015). The importance of organizational trust on organizational entrepreneurship. Applied mathematics in Engineering, Management and Technology,3(3), 422-426.

Rua, L., \& Araujo, C. (2016). Linking transformational leadership and organizational trust: has organizational commitment a mediating effect on it?. Cuadernos de Gestión,16(1), 43-62.

Rusu, R., \& Baboş, A. (2016). Organızational trust between institutional and interpersonal trust. Scientific Bulletin,2(40), 55-60.

Schermelleh-Engel, K., Moosbrugger, H., \& Müler, H. (2003). Evaluating the fit of structural equation models: tests of significance and descriptive goodness-of-fit measures. Methods of Psychological Research Online, 8(2), 23-74. 
Sezer, C. (2013). Kariyer olarak girişimcilik ve girişimcilik niyetini etkileyen faktörlerin içerik analizi ile belirlenmesi. Manas Sosyal Araştırmalar Dergisi,2(2), 49-60.

Shneor, R., \& Jenssen, J. I. (2014). Gender and entrepreneurial intentions. In kelley, l. (ed.), entrepreneurial women: new management and leadership models, Santa Barbara, CA: Praeger Publishing, 15-67.

Simpson, J. A. (2007). Foundations of interpersonal trust. In A. W. Kruglanski \& E. T. Higgins (Eds.), Social Psychology: Handbook of Basic Principles. New York, NY, US: Guilford Press.

Singh, U., \& Srivastava, K. B. L. (2016). Organizational trust and organizational citizenship behaviour. Global Business Review, 17(3), 594-609.

Sipahioğlu, M., \& Öner, M. (2013). Ortaöğretim kurumlarında çalışan öğretmenlerin örgütsel güven algıları. Ĕgitim ve Ögretim Araştırmaları Dergisi,2(3), 104-111.

Şimşek, S., \& Taşçı, A. (2004). Örgütlerde güven konsepti ve emniyet örgütü'nde güven modellerinin değerlendirilmesi. Polis Dergisi,34, 1-8.

Tokgöz, E., \& Seymen, O. A. (2013). Örgütsel güven, örgütsel özdeşleşme ve örgütsel vatandaşlık davranışı arasındaki ilişki: bir devlet hastanesinde araştırma. Öneri Dergisi,10(39), 61-76.

Uslu, F., \& Oklay, E. (2015). The effect of leadership on organizational trust. In: Leadership a Organizational Outcomes Meta analysis of Emprical Studies. Karadağ E., Eds., Springer, London/Berlin , Cham, 81-96.

Valliere, D. (2015). An effectuation measure of entrepreneurial intent. Procedia - Social and Behavioral Sciences, 169, 131-142.

Wibowo, B. (2017). Religiosity and entrepreneurial intention. Etikonomi,16(2), 187-206.

Yanık, O., Timuroğlu, M. K., \& Naktiyok, A. (2017). Üniversite duyguların girişimcilik niyeti üzerindeki etkisi. İşletme Araştırmaları Dergisi,9(2), 461-477.

Yılmaz, A. S. (2014). Bir sosyal değişim ajanı olarak girişimcilik eğitimi. Zeitschrift für die Welt der Türken,6(1), 297-310.

Yılmaz, E. (2005). Okullarda örgütsel güven ölçeğinin geçerlik ve güvenirlik çalışması. Selçuk Üniversitesi Sosyal Bilimler Enstitüsü Dergisi,14, 567-580.

Yı1maz, E., \& Sünbül, A. M. (2009). Üniversite öğrencilerine yönelik girişimcilik ölçeğinin geliştirilmesi. Selçuk Üniversitesi Sosyal Bilimler Enstitüsü Dergisi, 21, 195-203.

Yücel, C., \& Samanc1, G. (2009). Örgütsel güven ve örgütsel vatandaşlık davranış1. Fırat Üniversitesi Sosyal Bilimler Dergisi,19(1), 113-132.

Zaheer, A., Mcevily, B., \& Perrone, V. (1998). Does trust matter? exploring the effects of interorganizational and interpersonal trust on performance. Organization Science, 9(2), 141-159. 